\title{
STRATEGI PENGEMBANGAN ISTANA TAMBAKBULUSAN \\ SEBAGAI DESTINASI WISATA BAHARI \\ DI KABUPATEN DEMAK
}

\author{
Oleh : \\ Fajar Setyo Rahmanto \\ Jasanta Peranginangin \\ Made Prasta Yostitia Pradipta \\ (Dosen pada Sekolah Tinggi Pariwisata Sahid Surakarta)
}

\begin{abstract}
ABSTRAK
Skripsi ini mengkaji tentang strategi atau langkah-langkah yang diambil pengelola Istana Tambakbulusan dalam pengembangan Istana Tambakbulusan sebagai destinasi wisata bahari di Kabupaten Demak. serta kendala-kendala yang dihadapi dalam proses pengembangan. Penulisan skripsi ini menggunakan jenis penelitian deskriptif kualitatif untuk meneliti strategi pengembangan Istana Tambakbulusan sebagai destinasi wisata bahari di Kabupaten Demak. Metode pengumpulan data yaitu dengan wawancara dengan pengelola secara mendalam, selain itu pengumpulan data lainnya dilakukan dengan telaah dokumen dan observasi lapangan. Data yang diperoleh kemudian dianalisis secara kualitatif dengan metode triangulasi data dan disajikan secara deskriptif. Hasil dari penelitian ini menemukan bahwa strategi pengembangan atraksi di destinasi wisata bahari Istana Tambakbulusan ini akan menghidupkan kembali kegiatan atau event lama yang sudah tidak dilaksanakan lagi yaitu, "lomba perahu dayung". Serta dilakukan pengembangan fisik di area bibir pantai (reklamasi skala kecil) untuk menampung lebih banyak wisatawan. Selain itu pengembangan Amenitas yaitu memberikan tempat yang layak kepada UMKM untuk berjualan makanan, souvenir, dll. Aksesbilitas akan terus dilakukan pembangunan sesuai dengan rencana strategis pengembangan Istana Tambakbulusan. Sedangkan dari segi ancilarry service akan dilakukan perkoordinasian dengan warga desa untuk bersedia menyewakan rumah-rumah mereka untuk dijadikan homestay, dan juga akan menambah stakeholder terutama perusahan-perusahaan untuk memberikan CSR dalam membina warga Desa Tambakbulusan mengembangkan ancilarry service di Kawasan wisata bahari Istana Tambakbulusan. Kendalanya adalah kesulitan dalam mengedukasi masyarakat Desa Tambak Bulusan untuk turut sadar dan peduli akan pengembangan wisata di Desa Tambakbulusan dan berkenaan dengan keterbatasan anggaran dalam pembangunan serta kendala tentang kebersihan di dalam Kawasan wisata Istana Tambakbulusan.
\end{abstract}

Kata Kunci: Strategi Pengembangan Pariwisata, 4A, Istana Tambakbulusan, Wisata Bahari.

\section{ABSTRACT}

This skripsi examines the strategies or steps taken by the management of Istana Tambakbulusan in developing Istana Tambakbulusan as a marine tourism destination in Demak Regency. Including the constraints faced in the development process. The writing of this skripsi uses descriptive qualitative research to examine the strategy for developing Istana Tambakbulusan as a marine tourism destination in Demak Regency. The method of data collection is in-depth interviews with managers, in addition, other data is carried out by observation and field data. The data obtained were then analyzed qualitatively by data triangulation method and presented descriptively. The results of this 
study found that the strategy of developing attractions in the marine tourism destination of Istana Tambakbulusan will revive old activities or events that are no longer implemented, namely "rowing boat races". As well as physical development in the shoreline area (small scale reclamation) to accommodate more tourists. In addition, the development of amenity is to provide a proper place for UMKM to sell food, souvenirs, etc. Accessibility will continue to be carried out in accordance with the strategic plan for the development of the Istana Tambakbulusan. Meanwhile, in terms of ancillary service, coordination will be carried out with villagers to be willing to rent their houses for homestays, and will also add stakeholders, especially companies to provide CSR in fostering Tambakbulusan Village residents to develop ancillary services in the marine tourism area of Istana Tambakbulusan. The obstacle is the difficulty in educating the people of Tambakbulusan Village to be aware and care about tourism development in Tambakbulusan Village and with regard to budget constraints in development and constraints regarding cleanliness in the Istana Tambakbulusan tourist area.

\section{Keywords: Tourism Development Strategy, 4A, Istana Tambakbulusan, Marine Tourism.}

\section{PENDAHULUAN}

\section{Latar Belakang Masalah}

Wisata bahari adalah seluruh kegiatan yang dilakukan untuk menciptakan kesenangan, tantangan, pengalaman baru, kesehatan yang hanya dapat dilakukan di wilayah perairan. Wisata bahari dengan kesan penuh makna bukan semata-mata memperoleh hiburan dari berbagai suguhan atraksi dan suguhan alami lingkungan pesisir dan lautan tetapi juga diharapkan wisatawan dapat berpartisipasi langsung untuk mengembangkan konservasi lingkungan sekaligus pemahaman yang mendalam tentang seluk beluk ekosistem pesisir sehingga membentuk kesadaran bagaimana harus bersikap untuk melestarikan wilayah pesisir dimasa kini dan dimasa yang akan datang. Jenis wisata yang memanfaatkan wilayah pesisir dan lautan secara langsung maupun tidak langsung. Kegiatan langsung di antaranya berperahu, berenang, snorkeling (menyelam dipermukaan), diving (menyelam), memancing, dan lain-lain. Kegiatan tidak langsung seperti olahraga pantai, piknik, menikmati atmosfer laut, dan lain-lain (Nurisyah, 2001).

Kabupaten Demak memiliki berbagai destinasi wisata yang menarik untuk dikunjungi. Kabupaten Demak memiliki potensi obyek wisata cukup besar yang mempunyai daya tarik wisata untuk dikunjungi oleh wisatawan. Di Kabupaten Demak terdapat wisata alam, wisata buatan dan wisata religi. Wisata religi dengan tujuan makam Sunan Kalijaga dan masjid Agung Demak. Wisata Pantai Morosari di Sayung, Pantai Morodemak, Pantai Istambul di Tambakbulusan, Wisata Mangrove di Kedung mutih dan Taman Ria beberapa wisata budaya di daerah tertentu dan pada waktu tertentu (Probowati, Hanim, \& Wahyu, 2015).

Salah satu Destinasi wisata bahari di Demak yang sedang trend di media sosial adalah Istana Tambakbulusan (Istambul), karena di destinasi ini menawarkan 3 atraksi sekaligus dalam satu lokasi. Yaitu pantai Glagah Wangi, hutan mangrove, dan wahana susur perahu. Sejak dibukanya Pantai Istambul pada tahun 2016 yang semula bernama pantai Glagah Wangi yang terletak di Desa Tambak Bulusan Kecamatan Karang Tengah, untuk lebih mudah mengingat maka diberi nama ISTAMBUL. Berbagai upaya untuk mempromosikan pantai Istambul baik melalui media sosial dan Edukasi kini pantai Istambul sudah banyak pengunjungnya baik dari masyarakat Demak maupun dari luar kota Demak. Untuk hari biasa sekitar 200 pengunjung setiap harinya dan setiap hari libur sudah mencapai angka 2000 pengunjung (pariwisata.demakkab.go.id, 7 Juni, 2020).

Berdasarkan dari data Dinas Pariwisata Kabupaten Demak tersebut, secara umum dapat dikatakan bahwa objek wisata bahari Istana Tambakbulusan mengalami perkembangan yang sangat baik dalam konteks menarik wisatawan untuk berkunjung, mengingat jumlah kunjungan yang dapat 
mencapai 2000 pengunjung untuk objek yang dapat dikatakan masih baru, hal tersebutlah yang membuat penulis tertarik untuk mengetahui langkah-langkah atau strategi dalam mengembangkan destinasi tersebut sehingga menimbulkan daya tarik wisata bagi wisatawan.

Berdasarkan latar belakang yang diungkapkan diatas, serta hal-hal yang menarik yang ada di dalamnya maka penulis tertarik untuk mengadakan penelitian yang berjudul "Strategi Pengembangan Istana Tambakbulusan Sebagai Destinasi Wisata Bahari Di Kabupaten Demak".

\section{Rumusan Masalah}

Berdasarkan Latar belakang yang telah diuraikan diatas, dapat dirumuskan masalahmasalah sebagai berikut:

1. Bagaimana potensi Istana Tambakbulusan sebagai destinasi wisata bahari di Kabupaten Demak?

2. Bagaimana strategi pengembangan Istana Tambakbulusan sebagi destinasi wisata bahari di Kabupaten Demak?

3. Apa kendala yang dialami dalam pengembangan Istana Tambakbulusan sebagai destinasi wisata bahari di Kabupaten Demak?

\section{Tujuan Penelitian}

Penelitian ini bertujuan untuk:

1. Mengetahui potensi Istana Tambakbulusan sebagai destinasi wisata bahari di Kabupaten Demak.

2. Mengetahui strategi pengembangan Istana Tambakbulusan sebagi destinasi wisata bahari di Kabupaten Demak.

3. Mengetahui kendala yang dialami dalam pengembangan Istana Tambakbulusan sebagai destinasi wisata bahari di Kabupaten Demak.

\section{Manfaat Penelitian}

Manfaat penelitian ini antara lain:

1. Manfaat Praktis

Memberikan sumbangan ide atau pemikiran kepada pengelola Istana Tambakbulusan tentang strategi pengembangan Istana Tambakbulusan sebagai destinasi wisata bahari di Kabupaten Demak.

2. Manfaat Teoritis.

Selain manfaat praktis yang telah dikemukakan di atas, penelitian ini juga memiliki manfaat teoritis dalam menambah ilmu pengetahuan, wawasan serta landasan para peneliti lain dalam melakukan penelitian lain yang sejenis dalam pengembangan destinasi wisata bahari.

\section{LANDASAN TEORI}

\section{Pengertian Strategi Pengembangan \\ Pariwisata}

Suwantoro (2004:55) menyebutkan, strategi pengembangan kepariwisataan bertujuan untuk mengembangkan produk dan pelayanan yang berkualitas, seimbang dan bertahap. Berikut ini adalah langkah-langkah pokoknya:

1. Dalam jangka pendek dititik-beratkan pada optimalisasi, terutama untuk mempertajam dan menetapkan citra kepariwisataan, meningkatkan mutu tenaga kerja, meningkatkan kemampuan pengelolaan, Memanfaatkan produk yang ada, dan memperbesar saham dari pasar pariwisata yang telah ada.

2. Dalam jangka menengah dititik-beratkan pada konsolidasi, terutama dalam memantapkan citra pariwisata Indonesia, mengkonsolidasikan kemampuan pengelolaan, mengembangkan dan diversifikasi produk, dan mengembangkan jumlah dan mutu tenaga kerja.

3. Dalam jangka panjang dititik-beratkan pada pengembangan dan penyebaran dalam pengembangan kemampuan pengelolaan, pengembangan dan penyebaran produk dan pelayanan, pengembangan pasar pariwisata baru, dan pengembangan mutu dan jumlah tenaga kerja.

Pengembangan pariwisata adalah usaha yang dilakukan secara sadar dan berencana untuk memperbaiki obyek wisata yang sedang dipasarakan ataupu yang akan dipasarkan. Pengembangan tersebut meliputi perbaikan obyek dan pelayanan kepada wisatawan semenjak berangkat ati tempat 
tinggalnya menuju tujuan tinggal ke tempasemula (Yoeti, 2006:56). Sedangkan menurut Marpaung (2016:71). Proses pembentukan strategi adalah proses intelektual dan kreatif yang menitikberatkan pada kemampuan untuk memproyeksikan masa mendatang serta analisa yang tepat bagi kondisi-kondisi di masa yang akan datang.

\section{Pengertian Pariwisata Bahari}

Wisata pesisir dan bahari dapat memberikan peluang perdagangan bagi negara berkembang melestarikan dan melindungi ekosistem dan spesies. Alih-alih mengeksploitasi sumber daya laut secara berlebihan, laut dan wilayah pesisir dapat dimanfaatkan untuk pariwisata dan rekreasi yang berkelanjutan. Jika dirancang dengan cermat, aktivitas seperti selancar, selancar angin, dan kayak laut dapat dikembangkan menjadi tempat wisata berkelanjutan (Ghosh, 2011). Pariwisata bahari adalah suatu kegiatan perjalanan yang dilakukan oleh seseorang atau kelompok yang bersifat sementara untuk menikmati atau menyaurkan hobi yang berhubungan dengan kelautan, seperti menyelam, berenang, berselancar, memancing, dan lain-lain (Muljadi, 2014:219).

Wisata bahari adalah seluruh kegiatan yang dilakukan untuk menciptakan kesenangan, tantangan, pengalaman baru, kesehatan yang hanya dapat dilakukan di wilayah perairan. Wisata bahari dengan kesan penuh makna bukan semata-mata memperoleh hiburan dari berbagai suguhan atraksi dan suguhan alami lingkungan pesisir dan lautan tetapi juga diharapkan wisatawan dapat berpartisipasi langsung untuk mengembangkan konservasi lingkungan sekaligus pemahaman yang mendalam tentang seluk beluk ekosistem pesisir sehingga membentuk kesadaran bagaimana harus bersikap untuk melestarikan wilayah pesisir dimasa kini dan dimasa yang akan datang. Jenis wisata yang memanfaatkan wilayah pesisir dan lautan secara langsung maupun tidak langsung. Kegiatan langsung di antaranya berperahu, berenang, snorkeling (menyelam dipermukaan), diving (menyelam), memancing, dan lain-lain. Kegiatan tidak langsung seperti olahraga pantai, piknik, menikmati atmosfer laut, dan lain-lain (Siti Nurisyah, 2001).

Sedangkan menurut Soekadijo (1997:2), wisata bahari adalah wisata dan lingkungan yang berdasarkan daya tarik wisata kawasan yang didominasi perairan dan kelautan. Wisata bahari adalah kegiatan untuk menikmat keindahan dan keunikan daya tarik wisata alam di wilayah pesisir dan laut dekat 12 pantai serta kegiatan rekreasi lain yang menunjang. Wisata bahari adalah kegiatan wisata yang memanfaatkan potensi alam bahari sebagai daya tarik wisata maupun wadah kegiatan wisata baik yang dilakukan diatas permukaan di wilayah laut yang tidak dapat dipisahkan dari keberadaan ekosistemnya yang kaya akan keanekaragaman jenis biota laut.

\section{Pengertian Daya Tarik Destinasi Wisata}

Kata daya tarik itu sendiri berasal dari kata kerja bahasa Latin "atrathere", artinyamenarik (Gunn, 1987). Jadi dapat dikatakan bahwa jika beberapa karakteristik dari tujuan wisata ingin dipertimbangkan sebagai objek wisata, tentunya harus memiliki keistimewaan yang menarik dan berpotensi menarik turis. Daya tarik sering kali didefinisikan dengan mengacu pada fitur atau atribut tertentu dari suatu destinasi. Misalnya, beberapa studi menilai daya tarik destinasi dengan menjelajahi inventarisasi sumber daya dan daya tarik tujuan wisata yang ada (Backman, Uysal \& Backman, 1991; Ferrario, 1979), peneliti lain menyelidiki persepsi bahwa wisatawan memiliki sumber daya tujuan dan atraksi (Hu \& Ritchie, 1993; Kim, 1998; Ritchie \& Zins, 1978). Gearing dkk (1974), menemukan bahwa ada 4 daya tarik bagi wisatawan adalah keindahan alam, iklim, arsitektur, dan festival rakyat.

Attractiveness (Daya tarik suatu destinasi pariwisata) sering mengacu pada pendapat pengunjung tentang persepsi kemampuan destinasi tersebut untuk memenuhi kebutuhan mereka. Penelitian telah menunjukkan bahwa studi daya tarik diperlukan untuk memahami elemen yang mendorong orang untuk berwisata (Formica, 2002). Semakin suatu destinasi mampu memenuhi kebutuhan wisatawan, semakin destinasi dianggap menarik dan semakin besar pula 
kemungkinan destinasi tersebut yang akan dipilih daripada destinasi pesaing. Dengan demikian, nilai utama dari daya tarik destinasi adalah ketertarikan wisatawan pada destinasi tersebut (Kim \& Lee, 2002). Sedangkan menurut Mayo \& Jarvis (1981), Suatu destinasi pariwisata kedepannya merupakan gabungan dari atribut-atribut destinasi yang sebagian besar adalah turis fasilitas dan layanan. Dalam penilaian daya tarik suatu destinasi wisatawan mengevaluasi kemampuan yang dirasakan dari atribut destinasi untuk memenuhi kebutuhan mereka.

Sedangkan daya tarik destinasi wisata menurut Cooper dkk (1995: 81), mengemukakan bahwa terdapat 4 (empat) komponen yang harus dimiliki oleh sebuah objek wisata, yaitu, attraction (atraksi), accessibility (fasilitas), amenity (aksesbilitas), ancilliary (tambahan).

\section{Pengertian Attraction (Atraksi)}

Gunn (1972) menegaskan bahwa tanpa atraksi, tidak ada turis atau pariwisata. Kebalikannya juga benar karena 'atraksi pariwisata' ada karena turis dan mereka 'diproduksi' dan dipasarkan seperti itu karena ketersediaan wisatawan (Lew, 1987). Sedangkan Hu dan Wall (2005) mengatakan, "tempat-tempat wisata merupakan unsur penting untuk tujuan pariwisata yang sukses pembangunan". Senada dengan itu, Benur dan Bramwell (2015) menegaskan bahwa destinasi pariwisata mengandalkan pada produk utama pariwisata sebagai mekanisme untuk menarik dan memotivasi wisatawan untuk berkunjung.

Formica (2000) berpendapat bahwa layanan yang berkembang di sekitar atraksi sering kali menjadi atraksi itu sendiri. Misalnya, alat transportasi bisa menjadi daya tarik yang penting ketika itu adalah kapal pesiar atau kereta sejarah. Fasilitas penginapan dianggap sebagai atraksi penting jika orang-orang terkenal pernah menginap di sana. Oleh karena itu, ini penting untuk mengklasifikasikan dan menggabungkan berbagai atraksi pariwisata ke dalam kategori yang lebih sedikit, yaitu memiliki derajat homogenitas yang lebih tinggi untuk membuat sistem pariwisata yang lebih kompleks transparan dan mempelajari atraksi tersebut dengan lebih mudah.

Dalam literatur pariwisata dapat ditemukan berbagai klasifikasi tempat wisata. Klasifikasi dasar daya tarik pariwisata adalah yang diusulkan oleh UNWTO (Mc- Intyre, Hetherington \& Inskeep, 1993), yang mengklasifikasikan semua daya tarik destinasi faktor menjadi beberapa kategori berikut: sumber daya alam, warisan budaya \& sejarah, Kondisi iklim, Infrastruktur, dan Layanan dan fasilitas wisata.

\section{Pengertian Amenity (Fasilitas)}

Menurut Haneef (2018), amenitas adalah sarana dan prasarana yang perlu dibangun untuk melayani wisatawan. Mereka adalah elemen yang akan membawa kenyamanan dan kemudahan bagi para wisatawan selama berwisata. Amenitas adalah segala macam sarana dan prasarana yang diperlukan oleh wisatawan selama berada di daerah tujuan wisata. Sarana dan prasarana yang dimaksud seperti: penginapan, rumah makan, transportasi dan agen perjalanan. Dengan menggunakan prasarana yang cocok dibangunlah sarana-sarana pariwisata seperti hotel, atraksi wisata, marina, gedung pertunjukan, dan sebagainya. Adapun prasarana yang banyak diperlukan untuk pembangunan sarana-sarana pariwisata ialah jalan raya, persediaan air, tenaga listrik, tempat pembuangan sampah, bandara, pelabuhan, telepon, dan lain-lain (Suwena, 2010).

Secara umum, pelayanan suatu destinasi dapat dinilai dari kualitasnya, terutama kualitas yang dirasakan oleh wisatawan. Kualitas layanan yang dirasakan sangat penting bagi suatu destinasi, karena dapat berdampak signifikan pada kepuasan wisatawan dengan destinasi tersebut (Chadee \& Mattsson, 1996: 306). Fasilitas sebagai faktor dasar atau pendukung dari tujuan wisata dan faktor-faktor ini diperlukan untuk menawarkan pengalaman wisata yang memuaskan. Pengunjung dapat mengevaluasi persepsi mereka sebelumnya, berdasarkan pengalaman kunjungan mereka terhadap kualitas fasilitas yang ada, manajemen mereka dan masalah terkait, dan ini memiliki hubungan yang kuat 
dengan rekomendasi dan kunjungan berulang. (Hassan \& lankova, 2012).

\section{Pengertian Accessibility (Aksesbilitas)}

March (2004:10) menyatakan aksesibilitas mencakup jarak/waktu terbang, akses keseluruhan, frekuensi/kapasitas, akses masuk, penerbangan langsung/tidak langsung, persyaratan visa, kemudahan berjalan-jalan, kemudahan memperoleh sesuatu, informasi destinasi wisata, kemudahan menggabungkan perjalanan dengan destinasi wisata lainnya, kemudahan komunikasi. Kemudian menurut Cakici, Harman (2007:135), aksesibilitas mengacu pada keseluruhan sistem transportasi, terminal, dan kendaraan. Cakici, Harman (2007:139), aksesibilitas adalah akses mudah, kualitas jalan, fasilitas parkir, waktu mengemudi. Kaul (1985) adalah salah satu orang pertama yang menyadari pentingnya infrastruktur transportasi sebagai komponen penting dari pembangunan yang berhasil karena mendorong terciptanya atraksi baru dan pertumbuhan yang sudah ada.

Aksesbilitas adalah infrastruktur utama untuk tujuan wisata. Ini sangat penting di daerah di mana tempat-tempat wisata tersebar luas. Aksesibilitas mencakup jalan raya, kereta api, bandara, dan berbagai fasilitas transportasi (Haneef, 2018). Pentingnya infrastruktur untuk pariwisata telah ditekankan yang menganalisis produk dalam konteks keunggulan komparatif dan kompetitif, mereka menekankan bahwa, perencanaan dan pengembangan pariwisata tidak akan mungkin terjadi tanpa jalan, bandara, pelabuhan, listrik, limbah, dan air minum (Crouch \& Ritchie, 1999). Aksesibilitas destinasi diukur dengan jarak ekonomi yang dinyatakan dalam hamparan perjalanan. Kunci karakteristik aksesbilitas adalah seluruh system transportasi terdiri dari rute, terminal dan kendaraan (Stankovic, Dukic, 2009:24).

\section{Pengertian Ancillary Service (Pelayanan Tambahan)}

Sebagian besar wisatawan yang sedang berlibur pasti ingin terhibur, terhibur dan aktif selama kunjungan mereka. Dalam hal ini, mereka akan memerlukan informasi tentang layanan tambahan tujuan mereka, termasuk kegiatan dan atraksi. Fasilitas belanja, katering, dan wifi juga menjadi aspek penting produk pariwisata. Akses ke pusat bisnis, juru bahasa, layanan keuangan dan fasilitas komunikasi mungkin juga menjadi persyaratan yang diperlukan di destinasi wisata (Camillerie, 2018). Layanan sebuah destinasi penting dalam pilihan destinasi wisatawan. Di mata dari banyak wisatawan, destinasi berfungsi lebih efektif, saat layanan mereka banyak tersedia. Dengan demikian, kemakmuran pariwisata suatu destinasi sangat terkait dengan itu penyediaan berbagai layanan tambahan (Dwyer \& Kim, 2003).

Ancilliary juga merupakan hal-hal yang mendukung sebuah kepariwisataan, seperti lembaga pengelolaan, Tourist Information, Travel Agent dan stakeholder yang berperan dalam kepariwisataan (Suwena, 2010). Sedangkan Sunaryo, (2013), menjelaskan ancillary service lebih kepada ketersediaan sarana dan fasilitas umum yang digunakan oleh wisatawan yang juga mendukung terselenggaranya kegiatan wisata seperti bank, ATM, telekomunikasi, rumah sakit dan sebagainya. Sedangkan (Sugiama, 2011) menjelaskan bahwa ancillary service mencakup keberadaan berbagai organisasi untuk memfasilitasi dan mendorong pengembangan serta pemasaran kepariwisataan destinasi. Ancillary Services adalah layanan sekunder yang menunjang fasilitas dan merupakan fasilitas yang sangat penting untuk keberhasilan operasi semua bisnis pariwisata. (Reynish dkk 2009),

\section{METODE PENELITIAN}

\section{Jenis Penelitian}

Menurut Sukmadinata (2011:73), penelitian deskriptif kualitatif ditujukan untuk mendeskripsikan dan menggambarkan fenomena-fenomena yang ada, baik bersifat alamiah maupun rekayasa manusia, yang lebih memperhatikan mengenai karakteristik, kualitas, keterkaitan antar kegiatan. Selain itu, Penelitian deskriptif tidak memberikan perlakuan, manipulasi atau pengubahan pada variabel-variabel yang diteliti, melainkan menggambarkan suatu kondisi yang apa 
adanya. Satu-satunya perlakuan yang diberikan hanyalah penelitian itu sendiri, yang dilakukan melalui observasi, wawancara, dan dokumentasi.

Penelitian ini menggunakan teknik diskriptif yang menggunakan bentuk dan strategi deskriptif analisis kualitatif yang berhubungan dengan "Strategi Pengembangan Istana Tambakbulusan Sebagai Destinasi Wisata Bahari Di Kabupaten Demak" mengunakan teknik penelitian diskripsi kualitatif.

\section{Populasi}

Populasi adalah keseluruhan jumlah yang terdiri atas objek atau subjek yang mempunyai karakteristik dan kualitas tertentu yang ditetapkan oleh peneliti untuk diteliti dan kemudian ditarik kesimpulannya. (Sujarweni, 2014:65). Populasi dalam penelitian ini adalah beberapa 2 anggota BUMDes dan 2 orang paguyuban ojek perahu.

\section{Sampel}

Menurut Sujarweni, (2014:81) Sampel adalah bagian dari jumlah karakteristik yang dimiliki oleh populasi yang digunakan untuk penelitian. Teknik pengambilan sampel dalam penelitian ini menggunakan metode sampling insidental. Sampel adalah bagian dari sejumlah karakteristik yang dimiliki oleh populasi yang digunakan untuk penelitian. Kemudian sampel dalam penelitian ini adalah sebanyak 2 orang. Yaitu, Ketua Pengelola Istambul dan Kepala Desa Tambakbulusan

\section{Sumber Data}

Data primer adalah data yang diperoleh dari responden melalui kuesioner, kelompok focus dan panel atau juga data hasil wawancara peneliti dengan nara sumber. Sumber data yang langsung memberikan data kepada pengumpul data. Sedangkan data sekunder adalah data yang didapat dari catatan, buku, majalah, berupa laporan keuangan publikasi perusahaan, laporan pemerintah, artikel, bukubuku sebagai teori, dan lain sebagainya. Sumber yang tidak langsung memberikan data pada pengumpul data. (Sujarweni, 2014:73).

\section{Teknik Pengumpulan Data \\ - Wawancara}

Wawancara merupakan teknik pengumpulan data denganmengajukan pertanyaan secara langsung dengan narasumber, dengan cara mengadakan dialog atau wawancara secara langsung kepada pengelola, khususnya pengelola Objek Istana Tambakbulusan Demak.

\section{- Observasi}

Observasi adalah cara pengumpulan data dengan menggunakan jalan mengamati, meneliti atau melihat kejadian yang sedang berlangsung. Dalam melakukan penelitian ini, mengadakan observasi secara langsung, yaitu melakukan pengamatan secara langsung di Objek Istana Tambakbulusan Demak.

\section{- Studi Pustaka}

Pengumpulan data yang dilakukan yaitu dengan membaca, mengkaji serta mempelajari buku-buku, data-data dan bahanbahan yang berkaitan dengan bidang kepariwisataan. Studi pustaka dilakukan melalui referensi di Perpustakaan STP Sahid Surakarta dan dokumen-dokumen pengelola Objek Istana Tambakbulusan Demak.

\section{Teknik Analisis Data}

Metode deskriptif kualitatif adalah penelitian yang berusaha mendiskripsikan hubungan antara fenomena yang diteliti dengan sistematis, factual dan akurat, sifat-sifat serta hubungan antara fenomena yang diselidiki (Kusmayadi \& Sugiarto, 2009:29).

Triangulasi metode yaitu menyesuaikan informasi yang diperoleh dengan metode-metode yang berbeda yakni diantaranya adalah studi dokumen, observasi, dan wawancara. Teknik triangulasi yang digunakan oleh peneliti adalah pemeriksaan melalui sumber lainnya yang dapat dilakukan dengan cara sebagai berikut: 1) Menganalisis studi dokumen dengan melihat kandungan nilai karakter; 2) membandingkan data hasil observasi di objek atau pengamatan dengan studi dokumen; 2) membandingkan apa yang dikatakan oleh narasumber dengan data hasil observasi di objek ISTAMBUL; 3) membandingkan hasil wawancara pengelola 
objek ISTAMBUL dengan wawancara dari Dinas Pariwisata Kab. Demak. Proses triangulasi yang dilakukan peneliti dapat digambarkan sebagai berikut ini:

(Gambar: 3.1. Triangulasi Data)

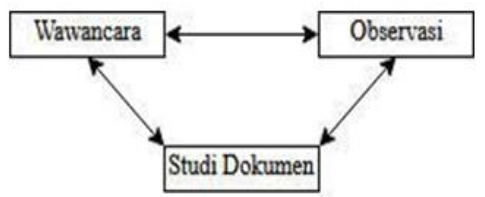

(Sumber: Sugiyono, 2008)

Proses triangulasi yang dilakukan peneliti melalui tiga sumber data yaitu data hasil wawancara, data hasil observasi, data hasil studi dokumen.

\section{HASIL DAN PEMBAHASAN}

\section{Identifikasi Potensi Istana Tambakbulusan Sebagai Destinasi Wisata Bahari di Kabupaten Demak Menggunakan Indikator $4 \mathrm{~A}$}

Potensi di Istana Tambakbulusan dapat diidentifikasi menggunakan indikator $4 \mathrm{~A}$, hal ini bertujuan mengkategorikan potensi Istana Tambakbulusan dengan masing-masing komponen 4A yaitu, atraksi, amenitas, aksesibilitas dan ancillary. Berikut ini adalah pengkategorian potensi dari hasil wawancara, studi dokumen, dan observasi lapangan yang dilakukan oleh penulis.

\section{- Potensi Atraksi di Istana Tambakbulusan}

Desa Tambakbulusan memiliki potensi bahari serta keindahan bentang alam yang indah, potensi atau daya tarik yang dimiliki objek wisata bahari Istana Tambakbulusan masih sangat bisa dikembangkan lebih luas. Bentang pantai berpasir serta ekosistem mangrove seluas kurang lebih $200 \mathrm{Ha}$ dan keragaman species mangrove dapat dinikmati melalui perjalanan menggunakan perahu merupakan potensi dasar dari objek wisata bahari Istana Tambakbulusan.

Atraksi di destinasi wisata bahari Istana Tambakbulusan secara garis besar dapat dikategorikan menjadi dua atraksi, yaitu atraksi utama yang menjadi daya tarik utama di Istana
Tambakbulusan. Atraksi kedua adalah atraksi pendukung yang bersifat atraksi tambahan yang terdapat didalam atraksi utama itu sendiri. Berikut ini adalah atraksi yang terdapat di destinasi wisata bahari Istana Tambakbulusan.

1. Atraksi Utama

Istana Tambakbulusan memiliki Atraksi

utama yang berupa rangkaian perjalanan. Dimulai dari Praonan adalah urutan atraksi pertama yang dilakukan di Kawasan wisata bahari Istana Tambakbulusan. Perahu-perahu ini dioperasikan oleh para nelayan yang beralih fungsi sebagai ojek perahu wisata. Bermula dari dermaga wisata didekat pintu masuk objek lalu wisatawan menaiki perahu menyusuri sungai selama kurang lebih 5 menit, setelah itu perahu akan bersandar di pintu masuk track mangrove

Rangkaian atraksi yang kedua adalah berjalan menyusuri teduhnya track mangrove. Wisatawan akan menikmati suasana hutan mangrove yang terletak di Istana Tambakbulusan, dan juga wisatawan dapat belajar mengenai jens-jenis mangrove dan sudah dilengkapi dengan papan informasi mengenai species mangrove. Sebagai informasi, hutan mangrove yang ada Istana di Tambakbulusan Memiliki seluas kurang lebih $200 \mathrm{Ha}$ dan Memiliki lebih dari 200 species mangrove. Setelah berjalan kurang lebih $300 \mathrm{~m}$, pada akhirnya wisatawan akan sampai pada sebuah pantai berpasir

Rangkaian atraksi yang ketiga
adalah menikmati keindahan pantai
berpasir yang bernama pantai Glagah Wangi. Setelah menyusuri hutan mangrove, wisatawan akan tiba di pantai Glagah Wangi dan sekaligus menjadi atraksi terakhir dari rangkaian atraksi utama di destinasi wisata bahari Istana Tambakbulusan. Pantai ini Memiliki daya tarik berupa pantai berpasir dan menjadi satu-satunya pantai berpasir di Kabupaten Demak, selain itu juga Memiliki anjungan yang menjorok ke pantai yang dapat digunakan oleh wisatawan untuk melihat pantai lebih dekat.

Atraksi utama diatas merupakan potensi dasar yang menjadi ide atau 
gagasan Kepala Desa Tambakbulusan untuk mengawali berdirinya destinasi wisata bahari Istana Tambakbulusan. Rangkaian atraksi diatas dikenakan harga sebesar Rp. 15.000, sudah termasuk ojek perahu, hutan mangrove, dan pantai Glagah Wangi.

2. Atraksi Pendukung

Atraksi pendukung yang terdapat di destinasi wisata bahari Istana Tambakbulusan sangat beragam, mulai dari atraksi untuk anakanak sampai atraksi untuk orang dewasa. Terdapat beberapa instalasi kayu yang dijadikan spot selfie yang berlatarkan laut yang dapat dimanfaatkan wisatawan yang berkunjung untuk berfoto atau selfie di Kawasan pantai Glagah Wangi. Selain itu terdapat pula ATV yang dapat dikendarai oleh wisatawan yang berkunjung untuk menjelajahi pantai, harga yang dikenakan untuk setiap 15 menitnya adalah sebesar RP. 20.000 .

Selain itu terdapat juga area bermain untuk anak-anak kecil, area bermain tersebut berupa kotak berjaring berukuran $3 \times 3$ meter sehingga saat anak bermain para orang tua tidak perlu khawatir apabila anaknya bermain di pantai. Area bermain ini dihargai Rp. 1000 untuk setiap jamnya untuk satu orang anak. Disisi lain juga terdapat persewaan alat-alat pendukung aktivitas di pantai seperti, ban karet, pelampung, pakaian renang, tikar dll.

Selain atraksi diatas terdapat juga maskot wisata yang bernama Si Tam-tam dan Si Bul-bul. Maskot wisata ini berwujud Kepiting dan Udang, kedua maskot tersebut selau stand by di panatai Glagah Wangi setiap harinya. Wisatawan dapat berfoto Bersama dengan $\mathrm{Si}$ Tam-tam dan Si Bul-bul dengan memberikan imbalan seikhlasnya.

\footnotetext{
- Potensi Amenitas di Istana Tambakbulusan

Amenitas adalah sarana dan prasarana yang perlu dibangun untuk melayani wisatawan. Mereka adalah elemen yang akan membawa kenyamanan dan kemudahan bagi para wisatawan selama berwisata. Amenitas adalah segala macam sarana dan prasarana yang diperlukan oleh wisatawan selama berada di daerah tujuan wisata (Sunitha, 2018).
}

Amenitas di destinasi wisata Istana Tambakbulusan dapat dikategorikan kedalam 3 area utama yaitu, area masuk dermaga, area track mangrove, dan area pantai Glagah Wangi. Dalam identifikasi amenitas tersebut maka peneliti akan mengidentifikasi amenitas di masing-masing area tersebut untuk mengetahui potensi apa saja yang terdapat di destinasi wisata bahari Istana Tambakbulusan yang berkaitan dengan amenitas. Berikut ini adalah identifikasi amenitas berdasarkan hasil observasi lapangan yang dilakukan oleh penulis yang terdapat di destinasi wisata bahari Istana Tambakbulusan.

\section{Area Masuk Dermaga}

Saat memasuki destinasi wisata bahari Istana Tambakbulusan terdapat loket masuk wisata dimana tiket masuk dijual, kondisi banguna loket masuk ini hanya terbuat dari papan triplek yang dicat dan masih dalam tahap pengembangan. Terdapat pula tempat parkir kendaraan bermotor dengan luas kurang lebih $10.000 \mathrm{~m}^{2}$ namun masih berupa tanah padas karena masih dalam proses pembangunan. Selain itu terdapat dermaga keberangkatan yang berfungsi sebagai tempat menaikkan wisatawan ke atas perahu yang menuju ke track mangrove. Selain fasilitas tersebut, terdapat juga Toilet di dekat tempat parkir kendaraan dan juga terdapat tempat ibadah (mushola) yang berupa Gazebo berkapasitas 20 orang. Mushola tersebut menurut keterangan ketua pengelola adalah hasil dari bantuan dana BANGUB, yaitu bantuan dana dari Gubernur Jawa Tengah. Terdapat pula tempat sampah disekitar area masuk dermaga, beberapa tempat sampah adalah bantuan CSR dari hotel Amantis Demak. Terakhir dan paling yang penting adalah adanya papan tata tertib wisatawan yang berisi himbauan kepada wisatawan untuk selalu menjaga keselamatan diri dan kebersihan lingkungan.

\section{Area Track Mangrove}

Amenitas yang berada di area track mangrove adalah dermaga kedatangan yang berfungsi sebagai tempat menurunkan wisatawan, didekat dermaga kedatangan juga terpampang papan informasi besar mengenai species mangrove yang adad di Istambul. Selain itu juga terdapat papan informasi yang 
tertempel di setiap mangrove yang menginformasikan tentang jenis mangrove itu sendiri. Beberapa gazebo dengan desain seperti rumah mini juga terdapat di sepanjang track mangrove berfungsi sebagai tempat istirahat untuk wisatawan yang lelah saat berjalan menyusuri track mangrove tersebut. Tempat sampah juga tersebar di sepanjang track mangrove untuk meminimalisir wisatawan membuang sampah pada area hutan mangrove.

\section{Area Pantai Glagah Wangi}

Dalam area panatai Glagah Wangi terdapat berbagai fasilitas publik yang dapaat dimanfaatkan oleh para wisatawan. Pertama adalah adanya tempat cuci tangan bantuan dari Kemenparekraf, karena pada saat peniliti melakukan observasi Istambul sedang menerapkan protokoler kesehatan karena adanya pandemi covid -19 , selain itu juga terdapat papan himbauan untuk selalu menjaga protokoler kesehatan selama berwisata di pantai Glagah Wangi.

Kemudian terdapat juga fasilitasfasilitas basic lain seperti tempat sampah, tempat bilas wisatwan setelah bermain di pantai, papan himbauan untuk selalu menjaga kebersihan, serta beberapa tempat makan dan souvenir. Area pantai Glagah Wangi sendiri juga menyediakan fasilitas yang dapat disewa oleh pengunjung yaitu sebuah Gazebo yang dapat digunakan untuk gathering keluarga, komunitas dll.

\section{- Potensi Aksesibilitas di Istana Tambakbulusan}

Aksesibilitas di destinasi wisata bahari Istana Tambakbulusan secara garis besar dapat dikategorikan menjadi beberapa kategori. Kategori tersebut mencakup kondisi jalan, akses transportasi, dan petunjuk jalan. Berikut ini adalah hasil identifikasi aksesbilitas berdasarkan observasi lapangan oleh peneliti di Kawasan wisata bahari Istana Tambakbulusan.

1. Kondisi Jalan

Kondisi Jalan menuju Kawasan Istana Tambakbulusan dapat dikatakan relativ baik, walaupun masih ada beberapa jalan yang masih akan dibangun. Jalan masuk utama menuju lokasi Istambul adalah melalui jalur pintura setelah itu masuk ke jalan utama menuju desa Wonowoso, Jalan disepanjang desa Wonowoso hingga mencapai Desa Tambakbulusan sudah di cor beton, akan tetapi jalan yang dari Desa Tambakbulusan menuju objek wisata bahari Istana Tambakbulusan masih berupa tanah padas, karena masih dalam tahap proses pembangunan jalan.

2. Akses Transportasi

Akses menuju destinasi wisata bahari Istana Tambakbulusan bisa dicapai dari Terminal Terboyo Semarang dengan menggunakan bus umum jurusan semarangdemak. Selain itu juga dapat menggunakan taxi, transportasi online, setelah mencapai jalan masuk dari pantura (Wonowoso), wisatawan juga bisa menyewa ojek konvensional yang stand by di jalan masuk Desa Wonowoso. Selain itu wisatawan juga bisa menggunakan kendaraan pribadi untuk menuju destinasi wisata bahari Istana Tambakbulusan. Wisatawan yang ingin berkunjung dapat menggunakan google maps untuk memudahkan mencari rute menuju destinasi wisata bahari Istana Tambakbulusan.

\section{Papan Penunjuk Jalan}

Penunjuk jalan adalah faktor penting untuk wisatawan menemukan sebuah objek wisata, hal ini memudahkan wisatawan untuk menemukan sebuah objek wisata. Sejauh ini masih belum ditemukan papan penunjuk jalan menuju destinasi wisata bahari Istana Tambakbulusan. Akibatnya wisatawan yang ingin berkunjung harus menggunakan google maps dan bertanya kepada warga setempat untuk mengetahui akses menuju destinasi wisata bahari Istana Tambakbulusan.

\section{- Potensi Ancilarry Service di Istana Tambakbulusan}

Ancilliary service merupakan hal-hal yang mendukung sebuah kepariwisataan, seperti lembaga pengelolaan, Tourist Information, Travel Agent dan stakeholder yang berperan dalam kepariwisataan (Suwena, 2010). Sedangkan Sunaryo, (2013), menjelaskan ancillary service lebih kepada ketersediaan sarana dan fasilitas umum yang digunakan oleh wisatawan yang juga mendukung terselenggaranya kegiatan wisata 
seperti bank, ATM, telekomunikasi, rumah sakit dan sebagainya.

Dalam mengidentifikasi ancilarry service di Istana Tambakbulusan dikategorikan dalam dua kategori yaitu, stakeholder kepariwisataan dan fasilitas publik. Fasilitas publik yang dimaksudkan disini adalah segala fasilitas yang diperlukan wisatawan di luar fasilitas yang disediakan oleh pengelola Istana Tambakbulusan. Berikut ini adalah indetifikasi ancilarry service atau fasilitas tambahan yang terdapat di destinasi wisata bahari Istana Tambakbulusan untuk membantu memenuhi kebutuhan wisatawan yang selama berkunjung destinasi wisata bahari Istana Tambakbulusan:

\section{Stakeholder Kepariwisataan}

Menurut Menteri Pariwisata Indonesia ke-14 Arif Yahya, model pentahelix adalah kolaborasi 5 (Lima Unsur) unsur subjek atau stakeholder pariwisata, yaitu: Academician, Business, Community, Government dan Media. Biasa disingkat ABCGM. Stakeholder kepariwisataan adalah ABCGM yang bekerjasama membantu berjalannya operasional wisata di Istana Tambakbulusan yaitu.

a. Academician, yaitu terdapat Universitas Gadjah Mada sebagai pendamping Istana Tambakbulusan dalam mengembangkan laboratorium mangrove.

b. Business, yaitu terdapat beberapa travel agent dari Demak dan Luar Demak yang membawatamu ke Istana Tambakbulusan hal ini dilakukan agar wisatawan kelompok (group) dapat mengunjungi destinasi wisata bahari Istana Tambakbulusan. Terdapat juga hotel yang menjual paket wisata untuk para tamu yang menginap di hotelnya. Hotel tersebut yaitu Hotel Amantis, yang terletak di pusat Kota Demak. Pelayanan mereka adalah mengantar dan menjemput tamu hotel mereka untuk berwisata di Istana Tambakbulusan.

c. Community, yaitu terdapat BPD (Badan Pengawas Desa) yang berfungsi sebagai pengawas berjalannya objek wisata bahari Istana Tambakbulusan. Terdpat juga Kelompok Sadar Wisata (POKDARWIS) yang melakukan pelatihan dan sosialisai tentang ilmu-ilmu kepariwisataan. Selain itu terdapat juga organisasi seperti LPMD (Lembaga Pemberdayaan Masyarakat Desa), Karang Taruna Desa Tambakbulusan, Paguyuban Ojek Perahu yang mendukung berjalannya operasionel objek wisata bahari Istana Tambak Bulusan. Terdapat pula UMKM yang menjual ikan segar dan olahan ikan yang dijual oleh warga setempat, namun mereka menjualnya diluar Istana Tambakbulusan. Warga menjualnya dirumah masingmasing,

d. Government, yaitu terdapat Dinas Pariwisata Demak yang membantu membangun track mangrove di Istana Tambakbulusan, Dinas Lingkungan dan Dinas Kelautan dan Perikanan yang membantu tentang konservasi mangrove dan pantai di Istambul. Pemerintah daerah Kabupaten juga menjadi mitra penting Istana Tambakbulusan dalam pembangunan akses disepanjang jalan menuju Desa Tambakbulusan.

e. Media, sejauh ini belum ada media cetak maupun online yang digandeng pengelola untuk mempromosikan Istana Tambakbulusan. Pengelola Istana Tambakbulusan selama ini menggunakan media sosial mereka sendiri seperti Istagram dan facebook untuk mengenalkan Istana Tambakbulusan sebagai destinasi wisata di Kabupaten Demak.

\section{Fasilitas Publik}

Fasilitas publik yang terdapat di dekat destinasi wisata Istana Tambakbulusan yang pertama adalah kantor Polisi. Kantor Polisi sendiri berjarak kurang lebih 10 menit dari destinasi wisata bahari Istana Tambakbulusan, dapat dikatakan relative jauh namun mudah dicapai karena akses jalan yang sudah bagus. Kemudian terdapat Puskesmas pembantu di Desa Tambakbulusan, yang memudahkan wisatawan yang ingin berobat atau sakit untuk segera ditangani. Jarak Puskesmas pembantu dari destinasi wisata bahari Istana Tambakbulusan dapat ditempuh hanya denagn 5 menit saja dengan kendaraan bermotor.

Selain itu terdapat juga ATM BCA yang berjarak 10 menit dari destinasi wisata bahari 
Istana Tambakbulusan untuk tamu yang ingin mengambil uang. Beberapa minimarket dan warung-warung kecil juga ada di destinasi wisata bahari Istana Tambakbulusan dan jaraknyapun tidak jauh dari lokasi Istambul. Beberapa warga juga menyewakan rumahnya untuk di jadikan homestay untuk memenuhi kebutuhan wisatawan yang ingin bermalam di Desa Tambakbulusan, harga yang dikenakan per malamnya relativ murah yaitu sebesar Rp. 50.000 .

\section{Identifikasi Strategi Pengembangan Istana Tambakbulusan Sebagai Destinasi Wisata Bahari Di Kabupaten Demak menggunakan Indikator 4A}

Strategi pengembangan Istana Tambakbulusan sebagai destinasi wisata bahari di Kabupaten Demak dapat diidentifikasi menggunakan indikator $4 \mathrm{~A}$, hal ini bertujuan mengkategorikan langkah-langkah strategi pengembangan Istana Tambakbulusan dengan masing-masing komponen 4A yaitu, atraksi, amenitas, aksesibilitas dan ancillary.

Berikut ini adalah pengkategorian langkah-langkah strategi pengembangan dari hasil wawancara dengan Kepala Desa Tambakbulusan dan Ketua BUMDes Istambul Karya dan melakuakan studi dokumen berupa rencana pengembangan atau master plan yang sudah dibuat oleh pengelola.

\section{- Strategi Pengembangan Atraksi di Istana Tambakbulusan}

Menurut Kepala Desa Tambakbulusan yang juga selaku komisaris dari BUMDes Istambul Karya yaitu Bapak Ahmad Chabibullah, S.Psi, menyebutkan bahwa strategi pengembangan Atraksi di destinasi wisata bahari Istana Tambakbulusan ini akan menghidupkan kembali kegiatan atau event lama yang sudah tidak dilaksanakan lagi. Kegiatan tersebut adalah "lomba perahu dayung", yaitu perlombaan balap perahu di Desa Tambakbulusan yang diharapkan dapat menarik wisatawan untuk melihatnya. Selain itu Kepala Desa Tambakbulusan juga menyebutkan akan membuat perlombaan menghias perahu secara periodik.
Sedangkan disisi lain Bapak Musahadi, S.Pi selaku Ketua BUMDes Istambul Karya, menambahkan, bahwa strategi pengembangan atraksi di Istana Tambakbulusan ada beberapa Langkah yang akan dilakukan. Pertama, wisatawan yang menaiki perahu nantinya akan diberikan pelampung keselamatan atau safety gear, hal ini bertujuan untuk keselamatan wisatawan menjadi prioritas pengelola Istana Tambakbulusan. Kedua, pengembangan pada track mangrove kedepannya akan dijadiakan ekowisata, eduwisata, dan kawasan konservasi. Untuk melakukan pengembangan di kawasan mangrove ini pengelola sudah menggandeng UGM untuk meneliti dan mendirikan" Laboratorium Mangrove", dan juga pengelola masih bernegosiasi tentang CSR dengan perusahan BUMN Pertamina dan perusahaan rokok Djarum untuk membantu mewujudkan hutan mangrove di Istana Tambakbulusan ini menjadi sebuah kawasan konservasi.

Selanjutnya yang ketiga adalah pengembangan bibir pantai, yaitu membuka lahan baru atau dapat dikatakan semacam reklamasi mini untuk menampung aktivitas wisatawan agar tidak hanya menggerombol di satu titik. Berikutnya pembuatan sabuk pantai atau pemecah ombak yang ditempatkan disisi luar pantai Glagah Wangi yang bertujuan untuk meminimalisir ombak besar yang langsung menuju ke pantai Glagah Wangi. Selain hal diatas akan dilakukan juga penambahanpenambahan atraksi pendukung seperti kereta mini, bis tayo, dan wahana permainan untuk anak. Itulah beberapa langkah pengembangan atraksi yang sedang dan akan dilaksanakan di destinasi wisata bahari Istana Tambakbulusan.

\section{- Strategi Pengembangan Amenitas di Istana Tambakbulusan}

Strategi pengembangan amenitas di destinasi wisata bahari Istana Tambakbulusan berdasarkan wawancara dengan Kepala Desa Tambakbulusan yang juga selaku komisaris dari BUMDes Istambul Karya yaitu Bapak Ahmad Chabibullah, S.Psi, kedepannya akan dibuat sebuah resto di kawasan Istana Tambakbulusan, namun beliau mengatakan tidak dalam waktu dekat ini. Senada dengan 
Kepala Desa Tambakbulusan, Ketua BUMDes juga menyebutkan akan dibangunnya satu resto besar dikawasan Istana Tambakbulusan. Namun Ketua BUMDes menambahkan akan memberikan tempat yang layak kepada UMKM untuk berjualan makanan, souvenir, dll.

Selain itu, menurut sumber dokumen berupa dokumen presentasi dari BUMDes Istambul Karya kedepannya akan dipasang Wifi di area pantai Glagah Wangi, karena apabila wisatawan yang sedang di pantai terkadang kesulitan mendapatkan sinyal telekomunikasi. Pantai Glagah Wangi nantinya akan dijadikan area outbound dan juga area camping zone, namun pengembangannya masih dalam proses. Itulah beberapa langkah pengembangan amenitas yang sedang dan akan dilaksanakan di destinasi wisata bahari Istana Tambakbulusan.

\section{- Strategi Pengembangan Aksesibilitas di Istana Tambakbulusan \\ Berdasarkan hasil dari wawancara} dengan Kepala Desa Tambakbulusan yang juga selaku komisaris dari BUMDes Istambul Karya yaitu Bapak Ahmad Chabibullah, S.Psi. Beliau mengemukakan bahwa pembangunan aksesibilitas akan terus dilakukan sesuai dengan rencana strategis pengembangan Istana Tambakbulusan, namun pembangunan infrastruktur ini memakan dana yang besar, jadi akan dilakukan secara perlahan dan mana dulu yang dapat dibangun. Beliau juga menyebutkan pembangunan aksesbilitas ini juga bergantung dengan pemerintah daerah maupun pemerintah provinsi, mengingat besaran dana yang dibutuhkan untuk membangun akses yang baik. Senada dengan Kepala Desa Tambakbulusan, Bapak Musahadi, S.Pi selaku Ketua BUMDes Istambul Karya juga mengatakan bahwa pembangunan aksesibilitas bergantung pada pemerintah daerah dan pemerintah provinsi. Beliau juga mencritakan bahwa Istana Tambakbulusan masuk dalam nominasi API (Anugerah Pesona Indonesia) 2020 yang diselenggarakan oleh Kementrian Pariwisata dan Ekonomi Kreatif, sehingga dengan masuknya Istana Tambakbulusan dalam nominasi dan juga dengan harapan bisa menang akan menarik perhatian pemerintah untuk membantu pembangunan aksesbilitas di destinasi wisata bahari Istana Tambakbulusan. Demikianlah beberapa langkah pengembangan aksesibilitas yang sedang dan akan dilaksanakan di destinasi wisata bahari Istana Tambakbulusan.

\section{- Strategi Pengembangan Ancilarry Service dii Istana Tambakbulusan \\ Kepala Desa Tambakbulusan} menyebutkan langkah strategi pengembangan Ancilarry Service di destinasi wisata bahari Istana Tambakbulusan sedang berkoordinasi dengan warga desa untuk bersedia menyewakan rumah-rumah mereka untuk dijadikan homestay. Selain itu juga sudah ada hotel yang bekerja sama untuk membawa tamu hotelnya untuk dibawa ke Istana Tambakbulusan yaitu hotel Amantis Demak. Kemudian Kepala Desa Tambakbulusan dan juga Ketua BUMDes Istambul Karya berharap menambah stakeholder terutama perusahanperusahaan untuk memberikan CSR dalam membina warga Desa Tambakbulusan mengembangkan ancilarry service di Kawasan wisata bahari Istana Tambakbulusan. Demikianlah beberapa langkah pengembangan amenitasi yang sedang dan akan dilaksanakan di destinasi wisata bahari Istana Tambakbulusan.

Kendala Yang Dialami Dalam Pengembangan Istana Tambakbulusan Sebagai Destinasi Wisata Bahari Di Kabupaten Demak

Adapun informasi mengenai kendalakendala yang dialami oleh pengelola dalam mengembangkan Istana Tambakbulusan sebagai destinasi wisata bahari di Kabupaten Demak diperoleh dari hasil wawancara dengan Kepala Desa Tambakbulusan yang juga selaku komisaris dari BUMDes Istambul Karya yaitu Bapak Ahmad Chabibullah, S.Psi. dan Bapak Musahadi, S.Pi. selaku Ketua BUMDes Istambul Karya mengetahui seluk beluk masalah dalam mengembangkan Istana Tambakbulusan.

Berikut ini adalah kendala-kendala yang dialami oleh pengelola dalam mengembangkan Istana Tambakbulusan 
sebagai destinasi wisata bahari di Kabupaten Demak.

1. Mengedukasi masyarakat Desa Tambak Bulusan untuk turut sadar dan peduli akan pengembangan wisata di Desa Tambakbulusan, maka dari itu pemerintah Desa membentuk POKDARWIS (Kelompok Sadar Wisata) untuk mengedukasi masyarakat desa agar lebih sadar tentang kepariwisataan.

2. Keterbatasan anggaran dari Desa untuk turut membantu pembangunan dalam konteks Pengembangan Istana Tambakbulusan sebagai destinasi wisata bahari di Kabupaten Demak.

3. Sampah juga menjadi kendala tentang kebersihan di dalam Kawasan wisata Istana Tambakbulusan. Masih banyak sampah yang berserakan dilokasi wisata yang diakibatkan dari wisatawan yang datang berkunjung dan membawa makanan dari luar lokasi wisata dan pada akhirnya dibuang sembarangan. Kedepannya pengelola akan memberikan larangan untuk wisatawan membawa makanan dari luar, sehingga selain kebersihan lokasi wisata yang didapat juga para penjual makanan dan minuman di dalam area wisata Istana Tambakbulusan juga akan lebih laku dan meningkat penjualannya.

Demikian adalah masalah atau kendalakendala utama yang dialami oleh pengelola dalam menggembangkan Istana Tambakbulusan sebagai destinasi wisata bahari di Kabupaten Demak.

\section{PENUTUP}

\section{Kesimpulan}

Kesimpulan dari penelitian ini menemukan bahwa strategi pengembangan atraksi di destinasi wisata bahari Istana Tambakbulusan ini akan menghidupkan kembali kegiatan atau event lama yang sudah tidak dilaksanakan lagi yaitu, "lomba perahu dayung". Serta dilakukan pengembangan fisik di area bibir pantai (reklamasi skala kecil) untuk menampung lebih banyak wisatawan. Selain itu pengembangan Amenitas yaitu memberikan tempat yang layak kepada UMKM untuk berjualan makanan, souvenir, dll. Aksesbilitas akan terus dilakukan pembangunan sesuai dengan rencana strategis pengembangan Istana Tambakbulusan. Sedangkan dari segi ancilarry service akan dilakukan perkoordinasian dengan warga desa untuk bersedia menyewakan rumah-rumah mereka untuk dijadikan homestay, dan juga akan menambah stakeholder terutama perusahanperusahaan untuk memberikan CSR dalam membina warga Desa Tambakbulusan mengembangkan ancilarry service di Kawasan wisata bahari Istana Tambakbulusan. Kendalanya adalah kesulitan dalam mengedukasi masyarakat Desa Tambak Bulusan untuk turut sadar dan peduli akan pengembangan wisata di Desa Tambakbulusan dan berkenaan dengan keterbatasan anggaran dalam pembangunan serta kendala tentang kebersihan di dalam Kawasan wisata Istana Tambakbulusan.

\section{Implikasi}

Berdasarkan hasil penelitian dari Strategi Pengembangan Istana Tambakbulusan sebagai destinasi wisata bahari di Kabupaten Demak, dapat dikemukakan implikasi bahwa konsep 4A bisa digunakan untuk mengidentifikasi potensi Istana Tambakbulusan sebagai destinasi wisata bahari di Kabupaten Demak. Selain itu konsep 4A juga dapat digunakan untuk mengidentifikasi langkahlangkah strategi dalam pengembangan Istana Tambakbulusan sebagai destinasi wisata bahari di Kabupaten Demak.

\section{Saran}

Berikut ini adalah beberapa saran berdasarkan hasil penelitian dari strategi pengembangan Istana Tambakbulusan sebagai destinasi wisata bahari di Kabupaten Demak.

1. Untuk pengembangan atraksi sebaiknya juga memperhatikan kebersihan objek atraksi itu sendiri, seperti kebersihan perahu yang mengangkut penumpang sebaiknya warna perahunya diseragamkan atau paling tidak dibuat konsep tematik tentang warna perahunya dan juga sebaiknya para ojek perahu diberikan seragam saat bertugas membawa tamu di Istana Tambakbulusan.

2. SDM sebagai pramuwisata di Istambul sebaiknya diberikan pelatihan-pelatihan 
mengenai pelayanan keramahtamahan terhadap tamu (hospitality).

3. Untuk pengembangan amenitas sebaiknya ditambahkan wi-fi disekitar area pantai, untuk memudahkan wisatawan mengakses jaringan internet saat di pantai. Selain itu sebaiknya loket masuk dan gerbang masuk dibuat dari bangunan yang layak dan menarik, mengingat sekarang masih terbuat dari bambu dan triplek. Selain itu juga tempat souvenir sebaiknya dibuat seragam dan tidak terkesan kumuh.

4. Untuk pengembangan aksesibilitas sebaiknya diupayakan segera untuk membuat papan penunjuk jalan ke lokasi Istana Tambakbulusan, sehingga wisatawan mudah untuk mengetahui lokasi objek.

5. Pemerintah Daerah setempat juga sebaiknya memberikan prioritas lebih untuk pembangunan jalan di Desa Tambakbulusan

6. Untuk pengembangan ancilarry service sebaiknya pemerintah Desa Tambakbulusan mengupayakan untuk menempatkan beberapa ATM didekat lokasi parkir Istambul.

7. Informasi mengenai homestay yang disewakan sebaiknya dipampang di area wisata Istana Tambakbulusan, sehingga tamu mengetahui bahwa ada tempat menginap di sekitar objek.

\section{DAFTAR PUSTAKA}

Backman, S., Uysal, M., \&. Backman, K. (1991). Regional Analysis of Tourism Resources. Annals of Tourism Research, 8(1), 323-7.

Benur, A. M. and B. Bramwell (2015). Tourism product development and product diversification in destinations. Tourism Management. 50: 213-224.

Cakici, A Celil., Harman, Serhat. (2007). Importance Of Destination Attributes Affecting Destination Choice of Turkish Birdwatchers. Journal of Commerce \& Tourism Education Faculty, Year: 2007 No: 1, Ticaret ve Turizm Egitim Fakültesi Dergisi.

Camilleri, M. A. (2018). The Tourism Industry: An Overview. In Travel Marketing, Tourism Economics and the Airline Product
(Chapter 1, pp. 3-27). Cham, Switzerland: Springer Nature.

Chadee, D. D., and Mattsson, J. (1996). An Empirical Assessment of Customer Satisfaction in Tourism. The Service Industries Journal. 16(3): 305-320.

Cooper, C., J. Fletcher, A. Fyall, D. Gilbert and S. Wanhill. (1993). Tourism Principles \&Practice. Longman Group Limited. England.

Crouch, G., \& Ritchie, B. (1999). Tourism, competitiveness and societal prosperity. Journal of Business Research, 44, 137152.

Dwyer, L., and Kim, C. 2003. Destination Competitiveness: Determinants and Indicators. Current Issues in Tourism. 6(5): 369-414.

Elahe Izad, Hasan Zabihi, Vali Alah Rahmani. (2016). The Role of Tourism in The Development of Coastal Villages. A Case Study in Noor Town, Iran. European Journal of Geography (ISSN 1792-1341) Volume 7, Number 4:67 - 79, December 2016. Association of European Geographers.

Erdoğan Koç. (2016). Turkish Marine Tourism An Untapped Market Segment with A Promising Potential: New Product and Destination Development Opportunities. Journal of Marine Tourism (ISSN: 25365215) Year: 1 Issue: 1 Volume: 1. Bandirma Onyedi Eylul University.

Ferrario, F. F. (1979). The evaluation of tourist resources: An applied methodology. Journal of Travel Research, 17(3), 18-22.

Formica, S. (2000). Destination attractiveness as a function of supply and demandinteraction. Unpublished doctoral dissertation. Virginia Polytechnic Institute and State University. Blacksburg.

Gearing, C., William, E., Swart, S., \& Var, T. (1974). Establishing a measure of touristic attractiveness. Journal of Travel Research, 12, 1-8.

Gunn, C. (1972). Vacationscape. Austin: University of Texas, Bureau of Business Research. 
Gunn, C.A. (1979, 1988). Vacationscape: Designing Tourist Regions. New York: Van Nostrand Reinhold.

Haneef, K. Sunitha. (2018). A Model to Explore the Impact of Tourism Infrastructure on Destination Image for Effective Tourism Marketing. School of the Built Environment University of Salford, United Kingdom.

Hassan A and lankovaK, (2012). Strategies and Challenges of Tourist Facilities Management in the World Heritage Site: Case of the Maritime Greenwich. London Tourism Analysis, Volume 17, Number 6, pp. 775-789(15).

Hu, W. \& Wall, G. (2005). Environmental management, environmental image and the competitive tourist attraction. Journal of Sustainable Tourism, 617-635.

Hu, Y. \& Ritchie, J.R. B. (1993). Measuring destination attractiveness: A contextual approach. Journal of Travel Research, 32(2), 25-34.

Kaul, R. N, Eds. (1985). Dynamics of tourism: a trilogy (vol. 111. Transportation and Marketing. New Delhi.

Kim, H. B. (1998). Perceived attractiveness of Korean destinations. Annals of Tourism Research, 25, 340-361.

Kim, S. S., \& Lee, C. K. (2002). Push and pull relationships. Annals of Tourism Research, 29(1), 257-260.

Kusmayadi \& Endar Sugiarto. (2000). Metodologi Penelitian Dalam Bidang Kepariwisataan. Jakarta: PT. Gramedia Pustaka Utama.

Lew, A.A. (1987). A Framework of tourist attraction research. Annals of Tourism Research, 14(4), 553-575.

Marpaung, Happy. (2016). Pengetahuan Kepariwisataan. Bandung: CV. Arfino Raya.

Mayo, E., \& Jarvis, L. (1981). Psychology of leisure travel. Boston: CABI Publishing.

Mclntyre, G., Hetherington, A. \& Inskeep, E. (1993). Sustainable tourism development: guide for local planners. Madrid: UNWTO.

Muljadi, A. J. (2014). Kepariwisataan dan Perjalanan. Jakarta: Raja Grafindo Persada.
Nurisyah, Siti. (2001). Rencana Pengembangan Fisik Kawasan Wisata Bahari di Wilayah Pesisir Indonesia. Buletin Taman Dan Lanskap Indonesia. Perencanaan, Perancangan dan Pengelolaan Volume 3, Nomor 2, 2000.Studio Arsitektur Pertamanan, Fakultas Pertanian, IPB Bogor.

Pariwisata.demakkab.go.id. (2019). Syawalan di Pantai Istambul Glagah Wangi. http://pariwisata.demakkab.go.id/?page_i $\mathrm{d}=376$. Diakses pada tanggal 7 Juni 2020.

Probowati, Hanim, Wahyu. (2015). Identifikasi Faktor Penentu Pengembangan Obyek Wisata Di Kabupaten Demak. Artikel IImiah Mahasiswa 2015. Jurusan IImu Ekonomi dan Studi Pembangunan, Fakultas Ekonomi, Universitas Jember.

Rahmani, V.Alah., Zabihi, Hasan., Izad, Elahe. (2016). The Role of Tourism in The Development of Coastal Villages: a Case Study in Noor Town, Iran. European Journal of Geography Volume 7, Number 4:67 - 79, December 2016. Association of European Geographers.

Reynish, N., Ivanovic, M., Khunou, P. S., Pawson, R., Tseane, L., \& Wassung, N. (2009). Tourism development 1: Fresh perspectives. Cape Town: Pearson Education and Prentice Hall.

Ritchie, B. J. R., \& Zins, M. (1978). Culture as a Determinant of the Attractiveness of a Tourist Region. Annals of Tourism Research, 5 (2), 252-67.

Soekadijo, R.G. (1997). Anatomi Pariwisata. Jakarta: PT Gramedia Pustaka Utama.

Stankovic, Ljiljana., Dukic, Suzana. (2009). Challenges of Strategic Marketing of Tourist destination Under The crisis Conditions. Series: Eco-nomics And Organization Vol. 6, No 1, 2009, page 23 31. Facta Universitatis.

Sugiama, A. G. (2011). Ecotourism: Pengembangan Pariwisata berbasis konservasi alam. Bandung: Guardaya Intimarta.

Sugiyono. (2008). Metode Penelitian Kuantitatif Kualitatif dan R\&D. Bandung: ALFABETA. 
Sukmadinata, S. Nana. (2011). Metode Penelitian Pendidikan. Bandung: PT. Remaja Rosdakarya.

Sunaryo, Bambang. (2013). Kebijakan Pembangunan Destinasi Pariwisata Konsep dan Aplikasinya di Indonesia. Yogyakarta: Gava Media.

Surjaweni V.W. (2014). Metodologi penelitian: Lengkap, praktis, dan mudah dipahami. Yogyakarta: Pustakabarupress.

Suwantoro, Gamal. (2004). Dasar-dasar Pariwisata, Yogyakarta: ANDI.
Suwena, I Ketut \& Widyatmaja, I Gst Ngr. (2010). Pengetahuan Dasar IImu Pariwisata. Bali: Udayana University Press.

Tuhin Ghosh. (2011). Coastal Tourism: Opportunity and Sustainability. Journal of Sustainable Development Vol. 4, No. 6; December 2011. School of Oceanographic Studies. Jadavpur University.

Yoeti, A. Oka. (2006). Perencanaan dan Pengembangan Pariwisata. Jakarta: Pradnya Paramitha. 